OSOBA I DUSZA

Filozofia Chrzé́cijańska • Tom 7, Poznań 2010

Uniwersytet im. Adama Mickiewicza • Wydzial TeOlogiczny

\title{
PRZEMYSŁAW STRZYŻYŃSKI
}

Uniwersytet im. Adama Mickiewicza Wydział Teologiczny

Zakład Filozofii Chrześcijańskiej

\section{Problem "nietoperza Nagel'a" w argumentacji Johna Hicka i Paula M. Churchlanda}

\section{The problem of the "Thomas Nagel's Bat" in the Argumentation} of John Hick and Paul M. Churchland

Klasyczny problem relacji dusza-ciało (mind-body problem), wraz z rozwojem nauk poznawczych, neuropsychologii czy neurofizjologii, podlega ciagłemu uszczegóławianiu. Z poziomu dosyć ogólnego poszukiwania miejsca styku duszy i ciała, jak u Kartezjusza, czy też poprawności językowego odróżniania duszy i ciała u Ryle'a, nauka - a w tym filozofia - przeszła do bardziej konkretnego pytania o relację mózgu i umysłu, w tym ludzkiej świadomości. Również na tym polu sporu obserwować można starcie dwóch wiodących podejść: naturalistycznego i takiego, które nie określa ludzkiej świadomości w terminach tylko fizjologicznych, tzw. nieredukacjonizm.

Wśród zwolenników nieredukcjonizmu znajduje się m.in. John Hick. Jego pośrednim adwersarzem jest m.in. Paul Churchland. Thomas Nagel, mimo że krytykuje redukcjonizm, nie wyklucza, że rozwój nowych koncepcji filozoficznych może pomóc w bardziej obiektywnym wyrażaniu subiektywności, co z kolei otwiera teoretyczną możliwość wyrażenia stanów umysłu językiem np. fizyki. Dyskusja przywołana w poniższym artykule nie odbyła się bezpośrednio między każdym z wymienionych autorów. Broniąc duchowo-cielesnej natury człowieka Hick przeciwstawia się redukcjonistycznym poglądom Churchlanda, przywołując argumentację Nagel'a, ale nie odnosi się do kontrargumentacji Churchlanda. Churchland natomiast krytykuje argumentację Nagel'a, ale nie odnosi się do Hicka. Punktem łączącym Hicka i Churchlanda 
jest argument Nagel'a. Dla Hicka jest to jeden z wielu argumentów wspierających odrzucenie mniej lub bardziej radykalnych poglądów sprowadzających umysł, świadomość do mózgu. Podobnie w moim artykule zajmować się będę tylko tym, fragmentarycznym aspektem sporu na temat relacji umysłu i mózgu.

\section{ARGUMENT NAGEL'A}

W artykule Jak to jest być nietoperzem? Nagel rozważa możliwość przejścia od subiektywnego doświadczania stanów mentalnych do ich obiektywnego przedstawienia ${ }^{1}$. Na tym zasadza się istota redukcjonizmu, że próbuje on sprowadzić dane samoświadomości do stanów mózgu, mierzalnych aparaturą naukową. W swoim argumencie Nagel próbuje przedstawić niemożliwość takiego wyrażenia. Doskonale wiemy, że nietoperze postrzegają świat przede wszystkim dzięki echolokacji i znamy jej mechanizm. Nagel stwierdza jednak, że choć echolokacja nietoperzy jest formą zmysłowej percepcji

nie działa podobnie do żadnego ze zmysłów jakie posiadamy i nie ma powodu przypuszczać, że z punktu widzenia nietoperza jest podobna do czegokolwiek, czego my możemy doznawać lub co możemy sobie wyobrazić².

Nawet jeśli można by sobie to wyobrazić, to zdaniem cytowanego autora, dowiemy się tylko, „,co by to znaczyło dla nas” [w tekście oryginalnym: „,dla mnie"] zachowywać się jak nietoperz ${ }^{3}$. Podczas gdy chcemy wiedzieć, jak to jest być nietoperzem dla nietoperza ${ }^{4}$.

Nagel rozszerza następnie powyższe stwierdzenia również na ludzi. Mimo że nie odmawiamy stanów subiektywnych innym ludziom i potrafimy wnioskować o ich nastrojach czy myślach, nie możemy powiedzieć, że przeżywamy ich subiektywne stany, ani że potrafimy je w pełni zobiektywizowaćs.

U podstaw takich wniosków leży, jak to nazywa Nagel, realizm wobec sfery subiektywnej. Jej realne istnienie ,implikuje przekonanie o istnieniu

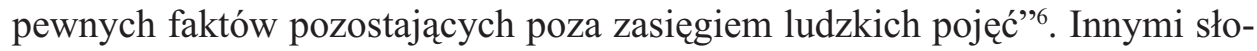
wy, stwierdza się tutaj niemożliwość pełnego wyrażenia stanów subiektywnych, czyli stanów świadomości. Tym samym podważona zostaje możliwość

${ }^{1}$ T. Nagel, Jak to jest być nietoperzem?, w: Pytania ostateczne, thum. A. Romaniuk, Warszawa 1997.

2 Tamże, s. 207.

${ }^{3}$ Tamże.

${ }^{4}$ Por. tamże.

${ }^{5}$ Por. tamże, s. 208.

${ }^{6}$ Tamże, s. 209. 
ich zobiektywizowania. Co więcej, jeśli doświadczenie jest w swym subiektywnym charakterze $\mathrm{w}$ pełni zrozumiałe tylko z jednego punktu widzenia, to żadne przejście do większej obiektywności - to znaczy do mniejszego związku ze szczególnym punktem widzenia - nie przybliża nas do rzeczywistej natury tego zjawiska. „Przeciwnie, oddala na od niego"7.

Jako wsparcie swojego poglądu Nagel przywołuje uwagi S. Kripkego. Zdaniem Nagel'a autor ten stwierdza, że

kauzalna analiza behawiorystyczna tego, co mentalne, i analizy jej pokrewne chybią celu, ponieważ interpretują na przykład wyrażenie «ból» jako tylko przygodną nazwę bólów. ...Subiektywny charakter doznań jest istotną własności, którą takie analizy pomijają

W końcowych uwagach Nagel nie wyklucza jednak, że rozwój filozofii pozwoli przynajmniej na częściowe zasypanie przepaści między subiektywnym a obiektywnym ${ }^{9}$.

\section{KONTRARGUMENTACJA CHURCHLANDA}

W książce pt. Mechanizm rozumu, siedlisko duszy. Filozoficzna podróż w głą mózgu Paul M. Churchland stara się m.in. wykazać, że argument Nagel'a mimo, że częściowo stwierdza prawdę, nie wykazuje nieredukowalności stanów umysłu do stanów mózgu. W następujący sposób Churchland streszcza argument Nagel'a:

nawet gdybyśmy potrafili odtworzyć doznania zmysłowe nietoperza na podstawie ich neurofizjologicznej charakterystyki, to i tak nie będziemy wiedzieli, jakie one są z unikalnej perspektywy istoty, która je ma. Specyficzny charakter tych doświadczeń pozostanie dla nas nieznany. Tak więc wiedza czysto fizyczna ma swoje granice, które nie pozwalają zgłębić subiektywnej natury treści świadomości ${ }^{10}$.

Wywody Nagel'a, często służą za argument zwolennikom nieredukcjoni$\mathrm{zmu}^{11}$.

7 Tamże, s. 213.

${ }^{8}$ Tamże, s. 214, przyp.11; por. S. Kripke, Nazywanie a konieczność, tłum. B. Chwedeńczuk, Warszawa 1988, s. 152.

${ }^{9}$ Por. tamże, s. 218.

${ }^{10}$ P. M. Churchland, Mechanizm rozumu, siedlisko duszy. Filozoficzna podróż w głąb mózgu, thum. Z. Karaś, Warszawa 2002, s. 217.

${ }^{11}$ Por. tamże. 
Churchland zgadza się, że każda istota ma wyłączny i jedyny dostęp do swoich podmiotowych doznań z tej racji, że

każde stworzenie, również nietoperz, korzysta z pewnego unikalnego zespołu wewnętrznych powiązań przyczynowych z aktywnością sensoryczną własnego mózgu i układu nerwowego. [...] Każdy zespół takich połączeń występuje zawsze tylko w obrębie jednego mózgu czy jednego ciała ${ }^{2}$.

Mimo że owe doznania są wyłączne, a zatem danych subiektywnych nie można zobiektywizować, to nie wynika z tego, że nie mają one charakteru materialnego ${ }^{13}$. Uzasadniając to stwierdzenie Churchland zauważa, że

dzięki sieci aksonów zwanej układem proprioreceptywnym człowiek ma pełny dostęp do informacji dotyczących położenia jego ciała i wzajemnego ułożenia członków. Ta informacja pochodzi od milionów receptorów znajdujących się w naszych ścięgnach, mięśniach szkieletowych i torebkach stawowych. Receptory przysyłają do mózgu dane o stanie napięcia mięśni i o zgięciu stawów. Nikt inny nie może poznać położenia twojego ciała $\mathrm{w}$ ten specyficzny sposób, tylko ty ${ }^{14}$.

Podobnie postrzegamy tzw. „gęsią skórkę”, rumienienie się twarzy itp. ${ }^{15}$ Churchland przyznaje, że nawet gdyby ze stuprocentową pewnością i dokładnością ktoś przedstawił owe poszczególne stany, nie dozna ich. Co wcale nie neguje ich materialnej natury ${ }^{16}$. Owa niemożliwość przejścia od subiektywnych stanów do obiektywnego ich przedstawienia oznacza, co najwyżej, że podmiotowe doznania przebiegają po niepowtarzalnych szlakach neuronowych. Nagel natomiast, w ujęciu Churchlanda, wnioskował, że niemożliwość ta oznacza istnienie niefizycznych własności umysłowych.

Na koniec swojej argumentacji Churchland pozostawia pewną dwuznaczność. Stwierdza najpierw, że możliwe jest, iż stany umysłu mają jakieś cechy niefizyczne, jak utrzymuje Nagel - mimo wadliwej argumentacji. Po czym, Churchland dodaje:

W rzeczywistości Nagel ze swoim przykładem znajduje się w jeszcze gorszym położeniu. Gdyby nawet bowiem takie niefizyczne cechy naprawdę miały istnieć, to dlaczego nasze introspekcyjne drogi nerwowe miałyby je dostrzec? Same te połączenia są bytami jak najbardziej fizycznymi. Jak mogłyby więc wejść w kontakt ze zjawiskami niematerialnymi? ${ }^{17}$

\footnotetext{
${ }^{12}$ Tamże.

${ }^{13}$ Por. tamże, s. 218.

${ }^{14}$ Tamże.

${ }^{15}$ Por. tamże.

${ }^{16}$ Por. tamże, s. 219.

${ }^{17}$ Tamże, s. 221.
} 
Zdaniem Churchlanda, jest bardziej prawdopodobne, że połączenia proprioreceptywne powstały w wyniku, „zwykłych selekcyjnych nacisków ewolucji biologicznej" 18 .

\section{ARGUMENT NAGEL'A W UJĘCIU HICKA}

W książce zatytułowanej The New frontier of religion and science. Religious experiance, neuroscience and the transcendent Hick prezentuje trzy zasadnicze grupy rozwiązań problemu relacji mózg/umysł: identyczności, pochodzenia i korelacji19. W wypadku identyczności mowa jest o tożsamości umysłu z mózgiem. Umysł jest traktowany jako coś fizycznego, a świadomość ,jest po prostu aktywnością neuronów" ${ }^{20}$. Chodzi oczywiście o aktywność elektro-chemiczną. Warto w tym miejscu zaznaczyć, że Hick przypisuje Churchlandowi ostrożność we formułowaniu twierdzeń o identyczności ${ }^{21}$. Niemniej opiera się tutaj na pracy Churchlanda z $1988^{22}$, a nie na omawianych powyżej (Mechanizmach rozumu...).

Drugą grupę poglądów nazywa Hick epifenomenalizmem, który głosi, że umysł jest

niefizycznym epifenomenem wytwarzanym przez funkcjonujący mózg, ale pozbawionym [ów umysł - P. S.] mocy sprawczej i istniejącym tylko w czasie poszczególnych neuronalnych procesów, których jest produktem ubocznym ${ }^{23}$.

Ostatnią grupę stanowią poglądy, których wspólną cechą jest korelacja między niezależnie istniejącymi mózgiem i umysłem ${ }^{24}$. Nie miejsce tutaj na streszczanie powyższych teorii. Warto jednak zauważyć, że proponowane przez Hicka kontrargumenty są interesujące i wydają się być rzetelnie przemyślane.

Wracając do problemu nietoperza, to pojawia się on jako jeden $\mathrm{z}$ argumentów przeciwko teorii identyczności. Streszczając argument Nagel'a, Hick stwierdza:

\footnotetext{
${ }^{18}$ Tamże.

${ }^{19}$ J. Hick, The New Frontier of Religon and Science. Religious experience, neuroscience and the transcendent, New York, 2006, s. 81.

${ }^{20}$ Tamże, s. 82.

${ }^{21}$ Por. tamże.

${ }^{22}$ P. Churchland, Matter and Consciousness, Cambridge, Massachusetts, s. 1, cyt. za: J. Hick, The New Frontier ..., dz. cyt., s. 83.

${ }^{23}$ J. Hick, The New Frontier..., dz. cyt., s. 92.

${ }^{24}$ Por. tamże, s. 83,106 n.
} 
kiedy wiemy wszystko, co można wiedzieć o anatomii nietoperza, jego fizjologii, sposobie lokalizowania za pomocą dźwięku raczej niż wzroku itd., wciąż - zakładając, że posiada on jakiś poziom świadomości - nie wiemy, jak to jest być nietoperzem $^{25}$.

Zdaniem Hicka, problem ten przedstawiany jest też przy pomocy prawa tożsamości. Mianowicie, jeśli A jest identyczne $\mathrm{z} B$, to posiadają one takie same atrybuty ${ }^{26}$. W tym kontekście, autor The New Frontier... stwierdza, że

stany umysłu nie są zlokalizowane przestrzennie, podczas gdy stany mózgu owszem tak; świadome uczucie bólu, na przykład, może być ostre, tępe lub pulsujące, natomiast żadna część mózgu sama w sobie nie staje się tępa, ostrzejsza ani też pulsująca. Kiedy ukłuję się w palec, cechy mojej świadomości bólu z pewnością nie są tym samym, co cechy serii wyładowań w neuronach mojego mózgu²7.

Jak widać, Hick wiernie oddaje część argumentacji Nagel'a. Pomija natomiast jego ogólne uwagi o problemie redukcji subiektywnego do podmiotowego. Nie odnosi się też do kontrargumentacji Churchlanda.

\section{WZAJEMNE RELACJE MIĘDZY OMAWIANYMI ARGUMENTACJAMI}

Przedstawione rozumowania zdają się, przy pierwszym spojrzeniu, odnosić do siebie jako klasyczna wymiana poglądów. Sądzę jednak, że nastąpiło tutaj pewne nieporozumienie. Dokładniejszy namysł pokazuje, że omawianym trzem autorom nie zawsze chodzi o to samo. Mimo że Nagel odrzuca możliwość wyobrażenia sobie jakieś reprezentacji stanów świadomości nietoperza i choć podkreśla problematyczność przejścia od podmiotowości do obiektywności, to jednak nie wyklucza, że pewne przynajmniej stany mentalne maja charakter fizyczny. Widać to, kiedy stwierdza:

myślę jednak, że istnieją też pewne racje, by sądzić, że doznania zmysłowe są procesami fizycznymi - choć nie potrafimy zrozumieć na czym to polega ${ }^{28}$.

Uwaga Nagel'a pozwala interpretować przykład nietoperza raczej właśnie jako przykład tylko, który ma służyć uwydatnieniu ogólnego problemu przejścia od subiektywności do obiektywności. Zwłaszcza że w tekście artykułu Jak to jest być nietoperzem? problem owego przejścia jest problemem głównym.

${ }^{25}$ Tamże, s. 85.

${ }^{26}$ Por. tamże.

${ }^{27}$ Tamże.

${ }^{28}$ T. Nagel, Jak to jest być nietoperzem?, dz. cyt., s. 217. 
Przy takiej interpretacji, kontrargument Churchlanda zgadza się, co prawda z tezą Nagel'a o niedostępności stanów podmiotowych, ale wykazanie ich fizycznej natury nie obala zastrzeżeń Nagel'a o niemożliwości, tymczasowej przynajmniej, przeżywania stanów świadomości innych osób albo nietoperza. Natomiast ostrze argumentu Churchlanda skierowane przeciwko domniemanemu odrzuceniu przez Nagel'a fizyczności owych stanów chybi celu, gdyż Nagel sam nie neguje możliwości owej fizyczności.

Co więcej, poglądy obu filozofów mogłyby zostać uzgodnione w kwestii przejścia od tego, co subiektywne do obiektywnego, o ile okaże się, że fizyczność stanów świadomości zostanie kiedyś jednoznacznie transformowana w stany podmiotowe innej osoby. Na razie jednak jest to pomysł, jak się wydaje, nawet teoretycznie watpliwy.

Wobec powyższego w swojej argumentacji Hick, podobnie jak Churchland, pomija uwagi Nagel'a o możliwej fizyczności stanów umysłowych. Przyjmuje natomiast jego rozważania jako oręż w walce $\mathrm{z}$ teorią identyczności. Niestety Hick pomija uwagi Nagel'a o ogólnym problemie przejścia od subiektywności do obiektywności. Przywołanie tych uwag wsparłoby argumentację Hicka przeciwko teorii identyczności. Tym bardziej okazałoby się to potrzebne, że Hick nie przeciwstawia się bezpośrednio kontrargumentacji Churchlanda.

\section{SUMMARY}

The article tries to show the relations between P. M. Churchland's and J. Hick's reference to T. Nagel's „bat argument” and is based on Nagel's, Mortal questions, Chuchralnd's The Engine of Reason, the Seat of the Soul. A Philosophical Journey into the Brain and J. Hick's The New Frontier of Religion and Science. Religious experience, neuroscience and the transcendent ${ }^{29}$.

The clue is that Churchland and Hick beg the main point of the Nagel's argument about the difference between mind and brain. Churchland agrees with Nagel in assuming of the self and only self knowledge about mind states. But the former author and Hick misunderstand that indeed Nagel argues that it is still impossible to identify subjective states as objective. Moreover, Hick avoids Churchland's counter-argument. Therefore, not all of the dispute concerns the same problem.

\section{Key words:}

T. Nagel, P. M. Churchland, J. Hick, mind-body problem, mind-brain problem, Nagel's bat, reductionism, antireductionism, identity theory, epiphenomenalism

${ }^{29}$ T. Nagel, Mortal questions, Cambridge 1979; P.M. Churchland, The Engine of Reason, the Seat of the Soul. A Philosophical Journey into the Brain, Cambridge, Massachusetts, London 1999; J. Hick, The New Frontier of Religion and Science. Religious experience, neuroscience and the transcendent, New York 2006. 